\title{
Originals
}

\section{Abnormal endothelial release of fibrinolytic activity and fibronectin in diabetic microangiopathy}

\author{
B. Haitas, A.J. Barnes, S. A. Cederholm-Williams'ㄹ, J. Moore, M. E. C. Shogry and R. C. Turner \\ Diabetes Research Laboratories, Radcliffe Infirmary and ${ }^{1}$ Department of Haematology, John Radcliffe Hospital, Headington, Oxford, UK
}

\begin{abstract}
Summary. Endothelial cell function in Type 1 (insulin-dependent) diabetic patients, both with and without retinopathy, was assessed by measuring the plasma fibrinolytic activity and fibronectin after $10 \mathrm{~min}$ venous stasis induced by a sphygmomanometer cuff. After venous stasis, diabetic subjects with proliferative retinopathy had fibrinolytic responses (median 0.13 increasing to $0.26 \mathrm{U} / \mathrm{ml}$ ) in the low normal range, which were significantly less $(p<0.005)$ than control subjects $(0.17-0.68 \mathrm{U} / \mathrm{mi})$ and diabetic patients with minimal retinopathy $(0.16-0.68 \mathrm{U} / \mathrm{ml} ; p<0.01)$. Plasma fibronectin levels were similar in the different groups, but after venous stasis, rose significantly in the diabetic patients, both in those with proliferative retinopathy (mean $317-399 \mu \mathrm{g} / \mathrm{ml} ; p<0.002$ ) and without retinopathy $(312-371 \mu \mathrm{g} / \mathrm{ml} ; p<0.05)$ but not in
\end{abstract}

normal subjects $(304-333 \mu \mathrm{g} / \mathrm{ml})$. These changes in fibrinolytic activity and fibronectin were independent of blood glucose, glycosylated haemoglobin, or indices of sensory or autonomic nerve function. These disturbances of endothelial function, together with known abnormalities of haemostatic variables and microvascular reflexes, might convert a usually temporary obstruction of capillary blood flow into a pathological capillary closure, and might contribute to the inexorable progression of advanced diabetic microangiopathy in spite of good diabetic control.

Key words: Fibrinolysis, fibronectin, Type 1 diabetes, retinopathy, diabetes control, microangiopathy.
The factors promoting diabetic microangiopathy are uncertain, and may involve platelet and coagulation abnormalities [1], and abnormal microvascular reflexes [2]. Local endothelial responses may be involved, with increased factor VIII related antigen in diabetic retinopathy $[3,4]$ indicative of endothelial dysfunction.

The endothelium produces plasminogen activator [5] and there are contradictory reports concerning fibrinolytic activity in diabetes in man [6-9]. Decreased fibrinolytic activity in response to venous stasis has been reported in diabetic patients with and without retinopathy, with a trend to those with long duration of diabetes and with retinopathy having a greater impairment [7]. In these studies, the patients have not been closely matched with control subjects, and have included different types of diabetes on different therapies.

Fibronectin is a glycoprotein present in plasma and in tissues where it acts as an adhesive [10]. It is produced by the endothelium $[11,12]$ and may affect the adhesion of blood cells to the endothelial surface [13]. It is found in increased amounts in the capillary walls and mesangium of diabetic glomeruli [14] and in the coronary arteries of diabetic subjects [15].
Fibrinolytic activity in blood increases after venous stasis [16], but the response of fibronectin has not been studied. We have investigated the plasma fibrinolytic and fibronectin changes after either venous stasis or ischaemia in the forearm of patients with Type 1 diabetes who have developed retinopathy, in a control group of long-standing diabetic patients with minimal evidence of microangiopathy, and in normal subjects.

\section{Subjects and methods}

\section{Subjects}

Two groups with long-standing Type 1 diabetes were studied (Table 1). Their basal insulin requirement was supplied by once daily ultralente insulin, and the prandial requirement by twice daily soluble insulin [17]. Eleven had proliferative retinopathy documented by colour photographs and fluorescein angiography. A second group of 10 patients had 'nil/minimal' evidence of retinopathy (fewer than five microaneurysms in a $30^{\circ}$ colour photographic field) despite a slightly longer duration of diabetes and no proteinuria. Sensory neuropathy of patients was assessed by measurement of vibration sensory threshold using the top scale of a biothesiometer [18] (Biomedical Instruments, Newbury, Ohio, USA), the precision $( \pm 1 S D)$ being $1.3 \mathrm{u}$. The patients with proliferative retinopathy were less sensitive than those with- 
Table 1. Clinical details of the normal and diabetic subjects studied

\begin{tabular}{|c|c|c|c|}
\hline & \multirow{2}{*}{$\begin{array}{l}\text { Normal } \\
\text { subjects } \\
(n=13)\end{array}$} & \multicolumn{2}{|c|}{ Diabetic patients } \\
\hline & & $\begin{array}{l}\text { 'Nil/minimal' } \\
\text { retinopathy } \\
(n=10)\end{array}$ & $\begin{array}{l}\text { Proliferative } \\
\text { retinopathy } \\
(n=11)\end{array}$ \\
\hline Age (years) & $47.3 \pm 7.6$ & $50.0 \pm 9.0$ & $44.5 \pm 9.3$ \\
\hline $\begin{array}{l}\text { Duration of } \\
\text { diabetes (years) }\end{array}$ & - & $27.0 \pm 4.8$ & $24.3 \pm 4.9$ \\
\hline Haemoglobin $\mathbf{A}_{\mathrm{tc}}(\%)$ & $7.4 \pm 0.7$ & $8.9 \pm 1.5$ & $8.8 \pm 1.3$ \\
\hline $\begin{array}{l}\text { Plasma glucose } \\
(\mathrm{mmol} / \mathrm{l})\end{array}$ & $4.5 \pm 1.2$ & $12.4 \pm 6.1$ & $13.0 \pm 7.1$ \\
\hline $\begin{array}{l}\text { Body mass } \div \\
\text { index }\left(\mathrm{kg} / \mathrm{m}^{2}\right)\end{array}$ & $26.0 \pm 3.5$ & $24.4 \pm 1.6$ & $25.2 \pm 2.5$ \\
\hline $\begin{array}{l}\text { Vibration sensory } \\
\text { threshold }(u)\end{array}$ & & $14.5 \pm 5.0$ & $22.0 \pm 7.9^{\mathrm{a}}$ \\
\hline $\begin{array}{l}\text { Proportional } \\
\text { increase in heart rate } \\
\text { on deep breathing }\end{array}$ & & $1.3 \pm 0.33$ & $1.17 \pm 0.16$ \\
\hline $\begin{array}{l}\text { Proportional } \\
\text { increase in heart rate } \\
\text { on standing }\end{array}$ & & $1.08 \pm 0.07$ & $1.06 \pm 0.06$ \\
\hline
\end{tabular}

Results expressed as mean \pm SD. a $p<0.05$, the two diabetic groups had significantly different vibration sensory thresholds

out $(p<0.05$; Table 1$)$. Autonomic neuropathy was assessed by the response to standing by measuring the degree of RR interval shortening at about 15 beats and lengthening at about 30 beats [19]. The RR variability in response to five deep breaths was also measured. The patients with proliferative retinopathy had a slight, but not significant impairment compared with those without $(p<0.1)$.

A group of 13 normal subjects with similar age, sex and body weight was studied during the same period (Table 1). None had a history of angina, myocardial infarction or other major vascular event.

The study was approved by the Ethics Committee of the Oxford Area Health Authority, and all patients gave informed consent.

\section{Blood sampling}

Samples were taken in hospital in the mid-morning, after the diabetic patients had their normal insulin and breakfast at home. All were rested for at least $30 \mathrm{~min}$ in a room whose ambient temperature was kept between $20.5^{\circ} \mathrm{C}$ and $24.4^{\circ} \mathrm{C}$

At the start of the test, a blood sample was taken with minimal venous compression for basal fibrinolysis and fibronectin, and for glycosylated haemoglobin level, assayed by the thiobarbituric method [20] and plasma glucose level measured by a glucose oxidase method (GOD-PERID, Boehringer, Mannheim, FRG).

Using a sphygmomanometer cuff, forearm venous stasis was achieved with a pressure of $80 \mathrm{mmHg}$. After $10 \mathrm{~min}$, a further sample was taken after insertion of an indwelling butterfly cannula. The cuff pressure was released, and blood samples were then taken at 10.5, 11, 12 and $15 \mathrm{~min}$.

Blood was anticoagulated with one-tenth volume trisodium citrate $(0.1 \mathrm{~mol} / \mathrm{l})$ and all samples were kept on melting ice until the last sample was drawn. Blood was centrifuged at $2800 \mathrm{~g}$ for $10 \mathrm{~min}$ at $4{ }^{\circ} \mathrm{C}$ and fibrinolytic activity measured within $30 \mathrm{~min}$. Euglobulin fractions were prepared and fibrinolytic activity measured using the fibrin plate method [21]. Lysis areas were converted to units by reference to a standard curve prepared from dilutions of purified urokinase $(0.01-10$ Committee of Thrombolytic Assay units/ml, Choay Institute, Paris, France). In view of the uncertain significance of the basal results, the absolute values after venous stasis were examined. Plasma citrate

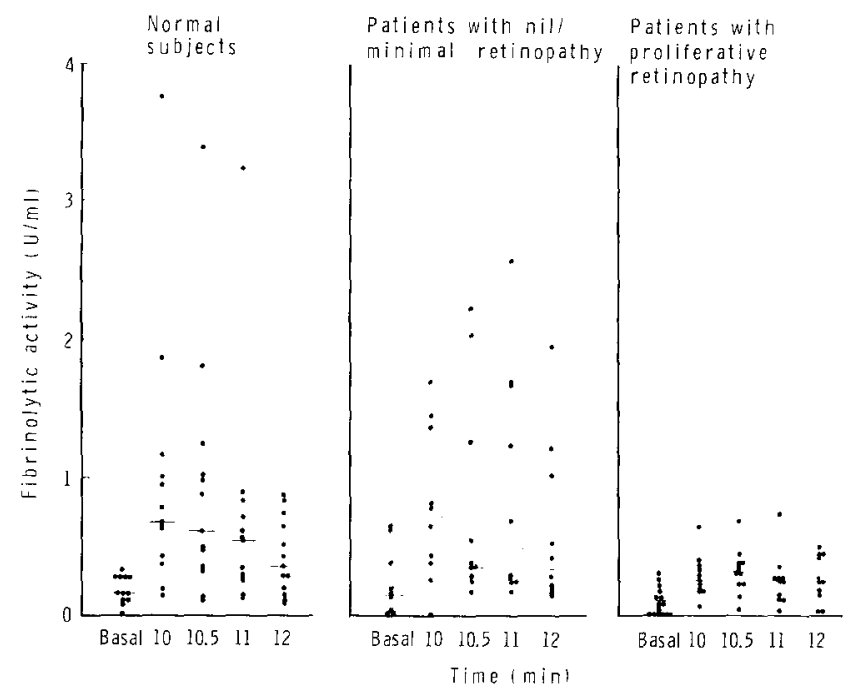

Fig. 1. Fibrinolytic activity in individual patients with median (-) before and after $10 \mathrm{~min}$ sphygmomanometer cuff occlusion at $80 \mathrm{mmHg}$. The results show samples taken at $10 \mathrm{~min}$ before the cuff was released, and at $0.5,1$ and 2 min later

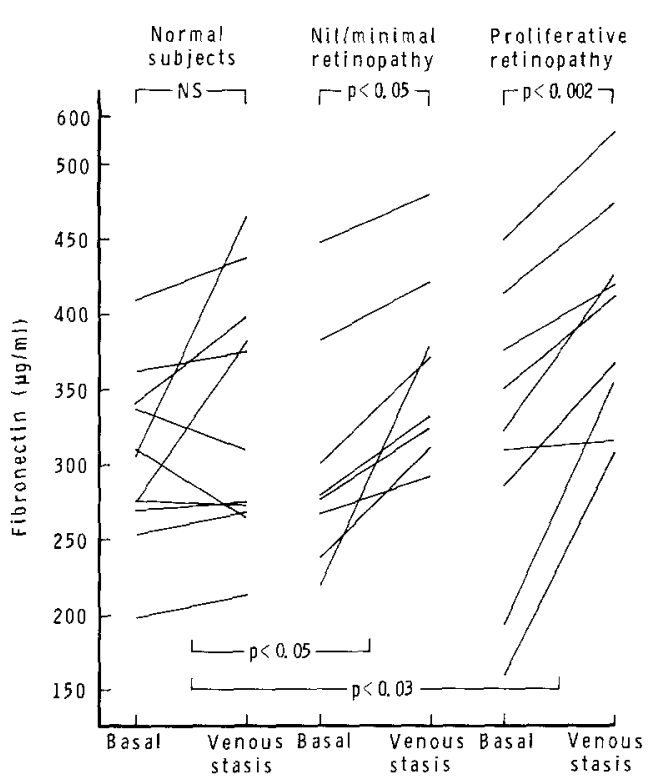

Fig. 2. Plasma fibronectin concentrations in individual patients before and at the end of $10 \mathrm{~min}$ sphygmomanometer cuff at $80 \mathrm{mmHg}$

samples were stored at $-20^{\circ} \mathrm{C}$ for later spectrophotometric assay of fibronectin, using an immunoturbidometric method (Boehringer, Ingelheim, FRG).

All samples were corrected for citrate dilution and haemoconcentration using the formulation:

$$
\frac{9\left(1-\mathrm{PCV}_{2}\right)+1}{9\left(1-\mathrm{PCV}_{1}\right)}
$$

where $P C V_{1}$ is the initial packed cell volume and $P C V_{2}$ is the packed cell volume for the subsequent sample [22].

Subjects also had vascular reactivity measured after $10 \mathrm{~min}$ forearm ischaemia induced by a sphygmomanometer cuff at $200 \mathrm{mmHg}$, using a transcutaneous oxygen monitor (Hellige, Freiburg, FRG) as reported previously [2]. Some subjects also had samples taken for fibrinolytic activity and fibronectin at the end of the ischaemic period. 


\section{Statistical analyses}

Statistical analysis was by Student's t-test (two-tailed) and correlation coefficient, except for non-parametric data which are expressed as medians, when the Mann Whitney U test and Spearman rank correlation [23] were used.

\section{Results}

The fibrinolytic activity before and after $10 \mathrm{~min}$ of venous stasis in the diabetic patients with and without retinopathy and in the normal subjects is shown in Figure 1. There was no difference in the unstimulated activity in the three groups. However, at 10, 10.5 and $11 \mathrm{~min}$, the group with proliferative retinopathy had a significantly reduced response compared with the normal subjects, the difference being greatest at $10 \mathrm{~min}$ (medians of the 0 and 10 min values were, respectively: 0.13 and 0.26 versus 0.17 and $0.68 \mathrm{U} / \mathrm{ml} ; p<0.005$ ). The patients with proliferative retinopathy had values in the low normal range. Compared with the 'nil/minimal' retinopathy group (medians of the 0 and $10 \mathrm{~min}$ values respectively: 0.16 and $0.68 \mathrm{U} / \mathrm{ml}$ ), the proliferative retinopathy group had a significantly reduced response, the difference being greatest at $10 \mathrm{~min}(p<0.01)$. There was no difference between the control subjects and the 'nil/minimal' retinopathy group at any time point.

Blood glucose, glycosylated haemoglobin and body mass index are shown in Table 1 . There were no significant differences between the diabetic groups with and without retinopathy. The fibrinolytic activity did not correlate significantly with the plasma glucose or glycosylated haemoglobin levels.

The plasma fibronectin levels were similar in all three groups. Figure 2 shows the response of plasma fibronectin to venous stasis in the two diabetic groups, with a significant increase following venous stasis in the 'nil/minimal' retinopathy group (mean \pm SD of the 0 and $10 \mathrm{~min}$ values were respectively: $312 \pm 65$ and $371 \pm 61 \mu \mathrm{g} / \mathrm{ml} ; p<0.05)$ and in the proliferative retinopathy group $(317 \pm 96$ and $399 \pm 71 \mu \mathrm{g} / \mathrm{ml} ; p<0.002)$ but not in the normal subjects $(304 \pm 57$ and $333 \pm$ $82 \mu \mathrm{g} / \mathrm{ml}$; NS) The rise in fibronectin after venous stasis (using a mean of values at $10,10.5$ and $11.5 \mathrm{~min}$ ) was greater in the proliferative retinopathy group compared with normal subjects $(p<0.03)$ and the 'nil/minimal' group compared with normal subjects $(p<0.05)$. There was no difference between the two diabetic groups. There was no correlation between basal or stimulated fibronectin and plasma glucose or glycosylated haemoglobin.

Fibrinolytic activity did not correlate significantly with the plasma fibronectin, with the hyperaemic response to ischaemia or to glycosylated haemoglobin or ambient blood glucose. Similarly, plasma fibronectin responses did not correlate significantly with the hyperaemic responses, glycosylated haemoglobin or blood glucose.
Fibrinolytic activity was assessed following $10 \mathrm{~min}$ forearm ischaemia in 10 control subjects and seven diabetic patients with 'nil/minimal' retinopathy. There was no rise in any group (basal, the mean of the 10 and the mean of the $11 \mathrm{~min}$ values were respectively: 0.17 and $0.12 \mathrm{U} / \mathrm{ml}, 0.26$ and $0.30 \mathrm{U} / \mathrm{ml}$ and 0.13 and $0.13 \mathrm{U} /$ $\mathrm{ml}$ ). Fibronectin response to ischaemia was assessed in three control and seven diabetic subjects (two without, five with retinopathy). There was no rise in either group (basal increasing to mean 10 and $11 \mathrm{~min}, 341$ to $350 \mu \mathrm{g} /$ $\mathrm{ml}$, and 340 to $343 \mu \mathrm{g} / \mathrm{ml}$, respectively).

\section{Discussion}

This study shows that diabetic patients with proliferative retinopathy had a reduced fibrinolytic activity in response to venous stasis, in the low normal range, although their unstimulated levels were comparatively normal. In contrast, patients who were specifically selected with a similar or slightly larger age and duration of diabetes, but who had not developed retinopathy, had a normal response. The diabetic state alone is not responsible for the defect. These results could be explained by either (1) microangiopathy resulting in failure of the vessel wall to respond to distension, or (2) by a low-normal release of fibrinolytic activity being a factor in the genesis of microangiopathy. The response is not secondary to ischaemia as neither normal nor diabetic subjects showed any response to $10 \mathrm{~min}$ with the sphygmomanometer cuff at $200 \mathrm{mmHg}$. The mechanism of plasminogen activator increase after venous stasis is poorly understood [5], but is likely to arise from distended capillaries. The low normal responses of diabetic patients with proliferative retinopathy may reflect a reduced number of capillaries in the hand and forearm, similar to that leading to retinal disease. The absence of correlation between fibrinolytic activity and variables of peripheral or autonomic nerve function suggests that the problem is not primarily one of innervation as suggested previously [7,25], but is at the local endothelial level. The lack of correlation with cutaneous hyperaemia following forearm ischaemia supports other work suggesting that the fibrinolysis release is independent of blood flow responses [24]. These data do not support the view that blood glucose control directly affects fibrinolytic activity [25]. Low fibrinolytic activity in the blood does not necessarily correlate with low histological plasminogen activator in the vessel walls, and it has been suggested that the low blood level is due to defective release of plasminogen activator [26].

Plasma fibronectin has been reported previously to be normal or raised in diabetes, with a suggestion that patients with retinopathy are particularly affected [27]. In this study, basal levels were similar in the normal and diabetic subjects, with sampling done carefully with minimal venous compression. However, after venous stasis, both diabetic groups had a significant rise. Those 
with proliferative retinopathy had a slightly greater, but non-significant, rise than those without retinopathy. Although fibronectin levels did rise slightly in the normal subjects this rise did not achieve statistical significance.

The abnormal fibrinolysis and fibronectin responses, regardless of their cause, may be factors promoting and perpetuating diabetic microangiopathy by impairing the ability of the microvasculature to dispose of an obstruction, including red cell rouleaux, a platelet aggregate or fibrin strands. The inter-relationship of $a b-$ normal vasoregulatory and haemostatic responses has been proposed in the pathogenesis of other ischaemic diseases [28]. These responses might convert an otherwise temporary obstruction into pathological capillary closure, and might contribute to the inexorable progression of advanced renal microangiopathy [29] or retinopathy [30] in spite of excellent metabolic control. Further studies are needed to determine whether patients with a low fibrinolytic response are a subgroup who are at increased risk of microangiopathy.

Acknowledgements. We are grateful to a grant from the Charles Wolfson Charitable Trust and to technical assistance from Mrs. R. Mullins and Mrs. S.Copper.

\section{References}

1. Bloom AL (1979) Blood and vascular interactions and their possible relevance to diabetic angiopathies. Medicographia $1: 3-8$

2. Haitas B, Barnes A, Shogry MEC, Weindling M, Rolfe P, Turner RC (1984) Delayed vascular reactivity to ischemia in diabetic microangiopathy. Diabetes Care 1: 47-51

3. Bensoussan D, Levy-Toledano S, Passa P, Cane J, Canivet J (1975) Platelet hyperaggregation and increased plasma levels of von Willebrand factor in diabetics with retinopathy. Diabetologia 11: 307-312

4. Porta M, Townsend C, Clover GM, Nanson M, Alderson AR, McCraw A, Kohner EM (1981) Evidence for functional endothelial damage in early diabetic retinopathy. Diabetologia 20:597-601

5. Hedner U, Nilsson IM (1981) The role of fibrinolysis. Clin Haematol 10: 327-342

6. Tanser AR (1967) Fibrinolytic responses of diabetics to adrenaline. J Clin Path 20: 231-233

7. Almer L, Pandolfi M, Nilsson IM (1975) Diabetic retinopathy and the fibrinolytic system. Diabetes $24: 529-534$

8. Bern MM, Cassani MP, Horton J, Rand L, Davis G (1980) Changes of fibrinolysis and factor VIII coagulant antigen and ristocetin cofactor in diabetes mellitus and atherosclerosis. Thrombosis Res 19: 831-839

9. Fuller JH, Keen H, Jarrett RJ, Omer T, Meade TW, Chakrabarti R, North WR, Stirling Y (1979) Haemostatic variables associated with diabetes and its complications. Br Med J 2: 964-966

10. Yamada KM, Olden K (1978) Fibronectins - adhesive glycoproteins of cell surface and blood. Nature 275: 179-184

11. Jaffe EA, Mosher DF (1978) Synthesis of fibronectin by cultured human endothelial cells. J Exp Med 147: 1779-1791

12. Clark RA, Quinn JH, Winn HJ, Lanigan JM, Dellepella P, Colvin $\mathrm{RB}$ (1982) Fibronectin is produced by blood vessels in response to injury. J Exp Med 156: 646-651
13. Wautier JL, Paton RC, Wautier MP, Pintigny D, Abadie E, Passa $P$, Caen JP (1981) Increased adhesion of erythrocytes to endothelial cells in diabetes mellitus and its relation to vascular complications. N Engl J Med 305: 237-242

14. Weiss MA, Ooi BS, Ooi YM, Engvall E, Ruoslahti E (1979) Immunofluorescent localisation of fibronectin in the human kidney. Lab Invest $41: 340-347$

15. Ledet T (1976) Diabetic cardiopathy. Quantitative histological studies of the heart from young juvenile diabetics. Acta Path Microbiol Scand 26: 798-803

16. Clarke RL, Orandi A, Clifton EE (1960) Induction of fibrinolysis by venous obstruction. Angiology 11: 367-370

17. Phillips M, Simpson RW, Turner RC (1979) A simple and logical twice daily subcutaneous insulin regime. Quart J Med: 48; 191; 493-506

18. Gregg EG (1951) Absolute measurement of the vibratory sensory threshold. Arch Nemol Psychiatry 66: 403-411

19. Ewing DJ, Campbell IW, Murray A, Neilson JM, Clarke BF (1978) Immediate heart rate response to standing: simple test for autonomic neuropathy in diabetes. Br Med J 1: 145-147

20. Ross IS, Gibson PF (1979) A semi-automated method for the determination of glycosylated haemoglobin. Clin Chim Acta 98: $53-59$

21. Astrup T, Mullertz S (1952) The fibrin plate method for estimation of fibrinolytic activity. Arch Biochim Biophys 40: 346-351

22. Chan TK, Chan V (1979) The effect of venous occlusion on antithrombin III, plasminogen activator and fibrinogen degradation product (fragment E) levels. Thrombosis Research 14: 525-534

23. Siegel S (1956) Non-parametric statistics for the behavioural sciences. McGraw Hill, New York

24. Chlmielewska J, Ranby M, Wiman B (1983) Evidence for rapid inhibitor to tissue plasminogen activator in plasma. Thrombosis Res 31: 427-433

25. Almer L-O, Lilja B, Lindell SE, Nilsson IM (1981) Endothelial factors in relation to peripheral circulation in diabetes. Thromb Res 20: $231-238$

26. Gunnarson R, Nyman D, Walinder O, Ostman J (1980) Fibrinolytic activity and diabetes control - evidence for a relationship. Acta Med Scand (Suppl) 639; 23-24

27. Davis TME, Moore JC, Turner RC (1984) Plasma fibronectin, factor VIII-RA and fibrinogen concentrations and diabetic retinopathy. Diabete Metab (in press)

28. Hellstrom HR (1982) The injury spasm (ischaemia-induced haemostatic vasoconstrictive) and vascular autoregulatory hypothesis of ischaemic disease. Am J Cardiol 49:802-808

29. Viberti GC, Bilous RW, MacKintosh D, Bending JJ, Keen H (1983) Long-term correction of hyperglycaemia and progression of renal failure in insulin-dependent diabetes. Br Med J 286: $598-601$

30. Lauritzen T, Frost-Larsen K, Larsen H-W, Deckert T and the Steno Study Group (1983) Effect of 1 year of near-normal blood glucose levels on retinopathy in insulin-dependent diabetics. Lancet $1: 200-203$

Received: 12 December 1983

and in revised form: 14 August 1984

Dr. R.C.Turner

Diabetes Research Laboratories

Radcliffe Infirmary

Woodstock Road

Oxford OX2 $6 \mathrm{HE}$

UK 